\title{
Catalytic Ethylene Polymerisation in Carbon Dioxide as a Reaction Medium with Soluble Nickel(II) Catalysts
}

\author{
Amaia Bastero, ${ }^{[\mathrm{a}]}$ Giancarlo Franciò,${ }^{[\mathrm{b}]}$ Walter Leitner, ${ }^{[\mathrm{b}]}$ and Stefan Mecking ${ }^{*[\mathrm{a}]}$
}

\begin{abstract}
A series of neutral $\mathrm{Ni}^{\mathrm{II}}$-salicylaldiminato complexes substituted with perfluorooctyl- and trifluoromethyl groups, $\left[\mathrm{Ni}\left\{\kappa^{2}-\mathrm{N}, \mathrm{O}-6-\mathrm{C}(\mathrm{H})=\mathrm{NAr}-2,4-\right.\right.$ $\left.\mathrm{R}_{2}^{\prime} \mathrm{C}_{6} \mathrm{H}_{2} \mathrm{O}\right\}(\mathrm{Me})$ (pyridine)] (6a: $\mathrm{Ar}=$ 2,6- $\left\{4-\left(\mathrm{F}_{17} \mathrm{C}_{8}\right) \mathrm{C}_{6} \mathrm{H}_{4}\right\}_{2} \mathrm{C}_{6} \mathrm{H}_{3}, \quad \mathrm{R}^{\prime}=\mathrm{I} ; \quad \mathbf{6 b}$ : $\mathrm{Ar}=2,6-\left\{4-\left(\mathrm{F}_{3} \mathrm{C}\right) \mathrm{C}_{6} \mathrm{H}_{4}\right\}_{2} \mathrm{C}_{6} \mathrm{H}_{3}, \quad \mathrm{R}^{\prime}=\mathrm{I}$; 6c: $\quad \mathrm{Ar}=2,6-\left\{3,5-\left(\mathrm{F}_{3} \mathrm{C}\right)_{2} \mathrm{C}_{6} \mathrm{H}_{3}\right\}_{2} \mathrm{C}_{6} \mathrm{H}_{3}$, $\mathrm{R}^{\prime}=3,5-\left(\mathrm{F}_{3} \mathrm{C}\right)_{2} \mathrm{C}_{6} \mathrm{H}_{3} ; \quad \mathbf{6 d}: \quad \mathrm{Ar}=2,6-\{4-$ $\left.\left(\mathrm{F}_{17} \mathrm{C}_{8}\right) \mathrm{C}_{6} \mathrm{H}_{4}\right\}_{2} \mathrm{C}_{6} \mathrm{H}_{3}, \quad \mathrm{R}^{\prime}=3,5-\left(\mathrm{F}_{3} \mathrm{C}\right)_{2}$ $\mathrm{C}_{6} \mathrm{H}_{3} ; \quad 6 \mathbf{e}: \quad \mathrm{Ar}=2,6-\left\{3,5-\left(\mathrm{F}_{3} \mathrm{C}\right)_{2} \mathrm{C}_{6} \mathrm{H}_{3}\right\}_{2}-$
\end{abstract}

$\mathrm{C}_{6} \mathrm{H}_{3}, \mathrm{R}^{\prime}=\mathrm{I}$ ) were studied as catalyst precursors for ethylene polymerisation in supercritical $\mathrm{CO}_{2}$. Catalyst precursors $\mathbf{6 a}$ and $\mathbf{6 c}$, which are soluble in $\mathrm{scCO}_{2}$, afford the highest polymer

Keywords: carbon dioxide
fluorinated ligands $\cdot$ homogeneous
catalysis $\cdot$ nickel $\cdot$ polyethylene
polymerization

yields, corresponding to $2 \times$ $10^{3}$ turnovers. Semicrystalline polyethylene $\left(M_{\mathrm{n}}\right.$ typically $\left.10^{4} \mathrm{~g} \mathrm{~mol}^{-1}\right)$ is obtained with variable degrees of branching (11 to 24 branches per 1000 carbon atoms, predominantly $\mathrm{Me}$ branches) and crystallinities (54 to $21 \%$ ), depending on the substitution pattern of the catalyst.

\section{Introduction}

Dense carbon dioxide, that is liquid or supercritical carbon dioxide $\left(\mathrm{scCO}_{2}\right)$, offers unique properties as a reaction medium, such as variation of the solvent properties through the density; volatility at ambient conditions, thus enabling facile removal of the solvent; environmental friendliness and non-toxicity. ${ }^{[1]}$ In reactions of gaseous substrates, the high miscibility of $\mathrm{scCO}_{2}$ with some gases can additionally help to avoid mass transport limitations, which are frequently encountered in such reactions. In polymerisation processes and polymer processing, the $\mathrm{CO}_{2}$ solvent or suspension medium, respectively, can be removed conveniently by reducing the pressure, resulting in a dry polymer product. This

[a] Dr. A. Bastero, Prof. Dr. S. Mecking

Universität Konstanz

Lehrstuhl für Chemische Materialwissenschaft

Fachbereich Chemie, Universitätsstr. 10

78457 Konstanz (Germany)

Fax : (+49) 7531-88-5152

E-mail: stefan.mecking@uni-konstanz.de

[b] Dr. G. Franciò, Prof. Dr. W. Leitner

Institut für Technische und Makromolekulare Chemie

RWTH Aachen, Worringer Weg 1

52074 Aachen (Germany)

Fax: (+49)241-80-22177

E-mail: leitner@itmc.rwth-aachen.de

Supporting information for this article is available on the WWW

under http://www.chemeurj.org/ or from the author. can be of interest, for example, to eliminate emissions of volatile organic compounds. The aforementioned unique properties of $\mathrm{CO}_{2}$ can be employed to control polymer morphologies. In some cases, the elimination of energy-intensive drying procedures may be environmentally and economically beneficial, though the effort for compression of $\mathrm{CO}_{2}$ must also be considered. ${ }^{[2]}$

Most studies of polymerisation in $\mathrm{CO}_{2}$ dealt with free-radical polymerisation, although an early example of cationic polymerization was reported in the $1960 \mathrm{~s}^{[3]}$ Interest increased considerably with the report of homogeneous polymerisation in $\mathrm{scCO}_{2}$ to afford soluble amorphous fluoropolymers in the $1990 \mathrm{~s} .{ }^{[4]}$ Free-radical polymerisation in $\mathrm{scCO}_{2}$ under heterogeneous conditions, either as precipitation, dispersion or emulsion polymerisations, has also been studied recently. Typical monomers investigated are methylmethacrylate,${ }^{[5]}$ styrene, ${ }^{[6]}$ vinyl acetate and acrylamide. ${ }^{[2]}$

By contrast to free-radical polymerisations, catalytic polymerisation offers control of polymer microstructures in general terms. ${ }^{[7,8]}$ Traditional Ziegler and metallocene catalysts are based on early transition metals. Due to their high oxophilicity, early-transition-metal complexes are likely to react with $\mathrm{CO}_{2}$. Late-transition-metal complexes are much less oxophilic, as demonstrated by the possibility of copolymerisation of polar monomers like acrylates ${ }^{[9]}$ and polymerisation in aqueous emulsions. ${ }^{[10,11,12]}$ Ring-opening metathesis polymerisation (ROMP) of norbornene and derivatives, ${ }^{[13,14]}$ polycarbonate synthesis from $\mathrm{CO}_{2}$ and epoxides ${ }^{[15,16]}$ and 
phenylacetylene polymerisation ${ }^{[17]}$ have been reported in $\mathrm{scCO}_{2}$ as a reaction medium. Ethylene polymerisation has been studied in $\mathrm{scCO}_{2}$ with Brookhart's palladium catalyst, with an emphasis on the analysis of the microstructure of the highly branched, amorphous polyethylenes formed. ${ }^{[18,19]}$ Also, the synthesis of polyketones by olefin/CO copolymerisation has been investigated. ${ }^{[20]}$

Ethylene polymerisation with neutral $\mathrm{Ni}^{\mathrm{II}}$ complexes has received renewed interest, as these catalysts are more functional-group tolerant than their cationic $\mathrm{Ni}^{\mathrm{II}}$ counterparts. ${ }^{[10,11,21]} \quad \kappa^{2}-\mathrm{N}, \mathrm{O}$-salicylaldiminato- $\mathrm{Ni}^{\mathrm{II}}$ complexes are very active for ethylene polymerisation, and afford high molecular weight polyethylene $\left(M_{\mathrm{n}}>10^{5} \mathrm{~g} \mathrm{~mol}^{-1}\right)$ at the same time. ${ }^{[21]}$ Remote substituents of the salicylaldiminato ligand can strongly influence the degree of branching and polymer molecular weight, by promoting or retarding $\beta$-hydride transfer. Thus, ethylene homopolymerisation affords polyethylenes ranging from semicrystalline, nearly linear to amorphous, highly branched. ${ }^{[22]}$ The unique combination of versatility and functional group tolerance prompted us to study polymerisation in $\mathrm{CO}_{2}$ as a reaction medium with these complexes. Nickel(II) complexes with perfluoroalkylsubstituted salicylaldimine ligands, which render them " $\mathrm{CO}_{2}$-philic", ${ }^{[23]}$ were prepared for this purpose.

\section{Results and Discussion}

Complex synthesis and properties: As outlined, remote substituents of $\mathrm{N}$-terphenylsalicylaldiminato- $\mathrm{Ni}^{\mathrm{II}}$ complexes have a strong impact on their polymerisation properties, namely molecular weight and degree of branching of ethylene homopolymers (Scheme 1). ${ }^{[2]}$ For example, whereas for $\mathrm{R}=\mathrm{CF}_{3}$ high molecular weight, nearly linear semicrystalline polyethylene is obtained $\left(M_{\mathrm{w}}=10^{5} \mathrm{~g} \mathrm{~mol}^{-1} ; 10\right.$ branches per $1000 \mathrm{C}$ atoms), a catalyst precursor with $\mathrm{R}=\mathrm{CH}_{3}$ affords highly branched, entirely amorphous low molecular-weight polymer $\left(M_{\mathrm{w}}=2.3 \times 10^{3} \mathrm{~g} \mathrm{~mol}^{-1} ; 76\right.$ branches per $1000 \mathrm{C}$ atoms).

Based on these insights, complexes were targeted with long-chain perfluoroalkyl substituents $\left(\mathrm{R}^{\mathrm{F}}\right)$, which should enhance solubility in $\mathrm{scCO}_{2},{ }^{[23]}$ but without insulating $-\mathrm{CH}_{2}-$ spacers. Perfluorinated octyl groups $\left(\mathrm{R}^{\mathrm{F}}=\mathrm{C}_{8} \mathrm{~F}_{17}\right)$ were introduced by copper-catalysed coupling, affording the aryl bromide 1. $^{[24]}$ In analogy to the synthesis of the aforementioned terphenyl-substituted salicylaldimines, ${ }^{[22,25]}$ transformation of bromide $\mathbf{1}$ into a boronic acid (2) followed by Suzuki coupling afforded aniline 3, which bears para- $\mathrm{R}^{\mathrm{F}}$ - substituted aryl groups in the 2,6-positions. Condensation of 3 with 3,5-diiodosalicylaldehyde yielded salicylaldimine 5a in $70 \%$ yield (Scheme 2 ).

Using a similar synthetic approach, aniline $\mathbf{3}^{\prime}$ bearing para- $\mathrm{CF}_{3}$-substituted aryl groups in the 2,6-positions was prepared, starting from 1-bromo-4-(trifluoromethyl)benzene, and converted to the corresponding imine $\mathbf{5 b}$ (Scheme 3).

Employing aldehyde $4^{\prime[26]}$ substituted with 3,5- $\left(\mathrm{CF}_{3}\right)_{2}-$ $\left(\mathrm{C}_{6} \mathrm{H}_{3}\right)$ groups introduces a higher number of fluorinated groups to the ligand backbone, ${ }^{[27]}$ and can also render the salicylaldimine ligand more electron withdrawing. Condensation with different anilines afforded salicylaldimines 5c and 5 d. Efforts to prepare a ligand containing para- $\mathrm{R}^{\mathrm{F}}$-substituted aryl groups in the aldehyde moiety, through Suzuki coupling of $\mathbf{1}$ and $\mathbf{4}$, failed. ${ }^{[28]}$

The aforementioned synthesis afforded a set of salicylaldimines $(\mathbf{5 a}-\mathbf{5} \mathbf{d})$ with systematically varied substitution patterns and a fluorine content ranging from 16-54 wt. \%. This degree of fluorination is well in the range required for $\mathrm{CO}_{2}$ solubility with catalytic species. ${ }^{[29]}$ Indeed, preliminary solubility experiments carried out with ligands $5 \mathbf{a}$ and $\mathbf{5 c}$ showed a sufficient solubility in supercritical $\mathrm{CO}_{2}$ at concentrations required for the use as a catalyst precursor. ${ }^{[30]}$

Reaction of $\left[\mathrm{Ni}(\text { tmeda })(\mathrm{Me})_{2}\right]^{[31]}$ (tmeda: N,N,N,N-tetramethylethylenediamine) with the corresponding fluorinated

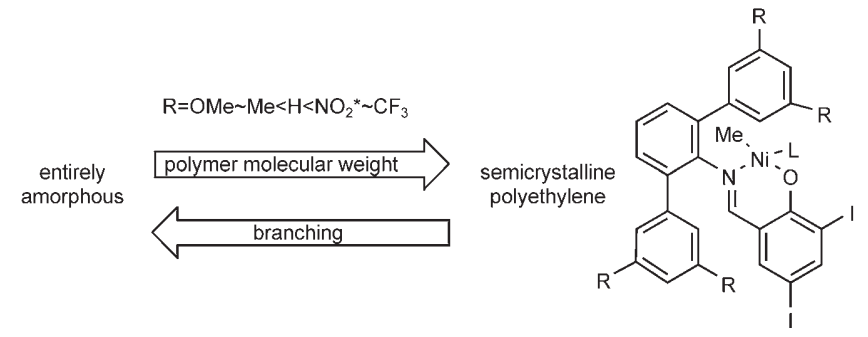

Scheme 1. Effect of remote substituents in ethylene polymerisation (*: monosubstitution only of the aryl groups for $\left.\mathrm{NO}_{2}\right) \cdot{ }^{[22]}$

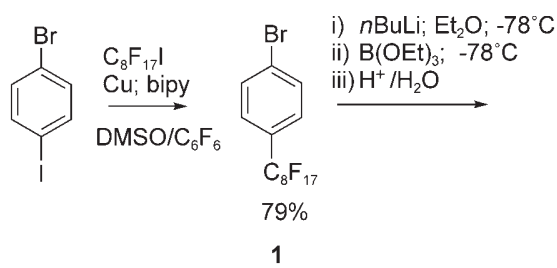

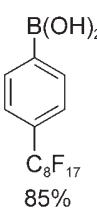

2

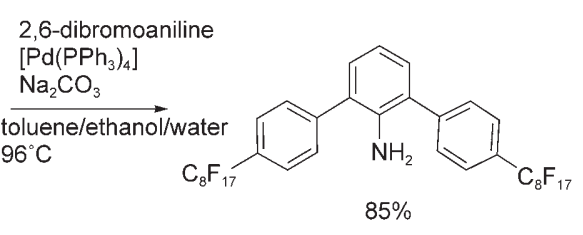

3

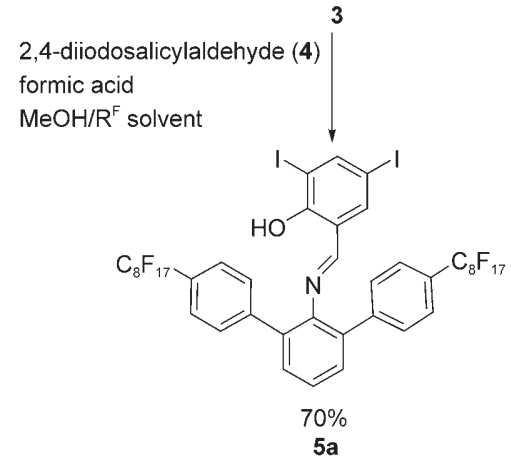

Scheme 2. Synthesis of perfluorinated salicylaldimine $\mathbf{5 a}$ 
<smiles>[R]c1cc(-c2cccc(-c3cc([R])c([R])c([R])c3)c2N)cc([R])c1[R]</smiles><smiles>[R]c1cc([R])c(O)c(C=O)c1</smiles><smiles>[R]c1cc([R])c(O)c(/C=N/c2c(-c3cc([R])c([R])c([R])c3)cccc2-c2cc([R])c([R])c([R])c2)c1</smiles>

$$
\begin{aligned}
& 3\left(R^{1}=\mathrm{C}_{8} \mathrm{~F}_{17} ; \mathrm{R}^{2}=\mathrm{H}\right) \\
& \mathbf{3}^{\mathbf{3}}\left(\mathrm{R}^{1}=\mathrm{CF}_{3} ; \mathrm{R}^{2}=\mathrm{H}\right) \\
& \text { 3" }^{\prime \prime}\left(\mathrm{R}^{1}=\mathrm{H} ; \mathrm{R}^{2}=\mathrm{CF}_{3}\right)
\end{aligned}
$$$$
4\left(R^{3}=1\right)
$$

5a $\left(R^{1}=\mathrm{C}_{8} \mathrm{~F}_{17} ; \mathrm{R}^{2}=\mathrm{H} ; \mathrm{R}^{3}=\mathrm{I}\right)(70 \%)$

$\mathbf{5 b}\left(\mathrm{R}^{1}=\mathrm{CF}_{3} ; \mathrm{R}^{2}=\mathrm{H} ; \mathrm{R}^{3}=\right.$ I) $(61 \%)$

5c $\left(\mathrm{R}^{1}=\mathrm{H} ; \mathrm{R}^{2}=\mathrm{CF}_{3} ; \mathrm{R}^{3}=3,5-\left(\mathrm{CF}_{3}\right)_{2}-\left(\mathrm{C}_{6} \mathrm{H}_{3}\right)\right)^{[26]}$

5d $\left(\mathrm{R}^{1}=\mathrm{C}_{8} \mathrm{~F}_{17} ; \mathrm{R}^{2}=\mathrm{H} ; \mathrm{R}^{3}=3,5-\left(\mathrm{CF}_{3}\right)_{2}-\left(\mathrm{C}_{6} \mathrm{H}_{3}\right)(76 \%)\right.$
Scheme 3. Fluorinated salicylaldimines prepared ligands in the presence of pyridine (py) afforded the neutral nickel methyl complexes $\left[\mathrm{Ni}\left(\kappa^{2}-\mathrm{N}^{\wedge} \mathrm{O}\right)(\mathrm{Me})(\mathrm{py})\right] \mathbf{6 a}-\mathbf{6}$ d. The complexes were isolated as air-stable orange or red solids. Characterisation in solution by ${ }^{1} \mathrm{H}$ and ${ }^{13} \mathrm{C}$ NMR spectroscopy shows the presence of a single isomer at room temperature for all compounds. The nickel-bound methyl group and the $\mathrm{O}$ donor atom are arranged in a trans position, as previously found for similar nickel-salicylaldiminato complexes (Scheme 4). ${ }^{[22,32]}$
$\mathrm{Ni}-\mathrm{Me}$ signal, nor variation of the pyridine signals were observed (see Figure S1 in Supporting Information). Under the conditions investigated, there is no evidence of any reaction of $\mathbf{6} \mathbf{b}$ with $\mathrm{CO}_{2}$.

Polymerisation experiments: Complexes 6a-6d, and for comparison also the known ${ }^{[22]}$ complex 6e (Scheme 4), were studied as catalyst precursors for ethylene polymerisation in supercritical carbon dioxide. The complexes were introduced as solids in a $10 \mathrm{~mL}$ stainless-steel high-pressure reactor equipped with thick-walled borosilicate windows. The vessel was pressurised with ethylene to 40 bar at room temperature, and $\mathrm{CO}_{2}$ was condensed in at $0^{\circ} \mathrm{C}$. Complexes $6 \mathbf{c}$ and 6d instantaneously dissolved affording a bright orange-red solution, which shows the high solubility of these precursors in compressed $\mathrm{CO}_{2}$. Complex 6a was completely soluble upon warming to $10^{\circ} \mathrm{C}$, whereas $\mathbf{6 e}$ was dissolved completely only at $20^{\circ} \mathrm{C}\left(\rho\left(\mathrm{CO}_{2}\right)=0.96 \mathrm{~g} \mathrm{~mL}^{-1}\right)$. For complex $6 \mathbf{b}$ almost no solubility was observed even at $50^{\circ} \mathrm{C}$ in neat $\mathrm{CO}_{2}$ $\left(p\left(\mathrm{CO}_{2}\right)=126\right.$ bar $)$, and therefore catalysis with this compound was not further studied.

Ethylene polymerisation with the different catalyst precursors was studied at $50^{\circ} \mathrm{C}$ (Table 1 ). The reaction could be followed visually through the windows of the pressure reactor. Upon warming to the reaction temperature, the orange solution became turbid already at $35^{\circ} \mathrm{C}$, indicating that polyethylene precipitated. After $1 \mathrm{~h}$ of reaction, significant amounts of polymer had precipitated and the reactor was carefully vented, extracting at the same time unreacted monomer or any low-molecularweight oligomers of ethylene. The polyethylene formed was obtained as a dry powder.

It has been documented that nickel complexes can react with $\mathrm{CO}_{2}$, which would result in catalyst deactivation. ${ }^{[33]}$ For example, insertion of carbon dioxide into a $\mathrm{Ni}$-ethyl bond of $\left[\mathrm{Ni}(\mathrm{Et})_{2}(\right.$ bipy) $]$, to afford diethylketone and the nickel propionate complex $\left[\mathrm{Ni}(\mathrm{Et})\left(\mathrm{OCO}_{2} \mathrm{Et}\right)(\right.$ bipy $\left.)\right]$, has been reported. ${ }^{[34]}$ We studied the reactivity of $\mathbf{6} \mathbf{b}$ towards $\mathrm{CO}_{2}$ by bubbling $\mathrm{CO}_{2}$ through a solution of $\mathbf{6} \mathbf{b}$ in $\left[\mathrm{D}_{6}\right]$ benzene for an hour at room temperature. Neither disappearance of the
True catalyst activities cannot be derived from the present data, as no conversion/time profiles are available. From the observation of immediate onset of turbidity it appears that there is no significant induction period. Furthermore, the total turnover numbers $(\mathrm{TON}=\mathrm{mol}($ ethylene $) / \mathrm{mol}(\mathrm{Ni}))$ at identical reaction times provide evidence for the relative catalyst performance. Overall productivities are highest with $\mathbf{6 a}$ and $\mathbf{6 c}$, approaching $2 \times 10^{3}$ TONs within one hour. Note 
Table 1. Ethylene polymerisation in $\mathrm{scCO}_{2}$ with various complexes as catalyst precurors. ${ }^{[\mathrm{a}]}$

\begin{tabular}{|c|c|c|c|c|c|c|c|c|}
\hline & $\begin{array}{l}\text { Catalyst } \\
\text { precursor }\end{array}$ & $\begin{array}{l}\rho\left(\mathrm{CO}_{2}\right) \\
{\left[\mathrm{g} \mathrm{mL}^{-1}\right]}\end{array}$ & $\begin{array}{l}\text { Initial pressure } \mathrm{e}^{[\mathrm{b}]} \\
{[\mathrm{bar}]}\end{array}$ & $\mathrm{TON}^{[\mathrm{c}]}$ & $\begin{array}{l}T_{\mathrm{m}}{ }^{[\mathrm{d}]} \\
{\left[{ }^{\circ} \mathrm{C}\right]}\end{array}$ & $\begin{array}{c}\text { Crystallinity } \\
{[\%]^{[\mathrm{d}, \mathrm{e}]}}\end{array}$ & Branches $^{[\mathrm{f}]}$ & $M_{\mathrm{w}}{ }^{[\mathrm{g}]}\left(M_{\mathrm{w}} / M_{\mathrm{n}}\right)$ \\
\hline 1 & $6 a$ & 1.00 & 300 & 2079 & $102-116$ & 39 & 24 & $2.0 \times 10^{4}(4.4)$ \\
\hline 2 & $6 c$ & 0.99 & 282 & 2015 & 125 & 52 & 17 & $6.5 \times 10^{4}(3.1)$ \\
\hline 3 & $6 d$ & 0.94 & 292 & 125 & 74 & 21 & n.d..$^{[i]}$ & $2.9 \times 10^{3}(3.7)^{[\mathrm{h}]}$ \\
\hline 4 & $6 e$ & 0.96 & 253 & 1566 & 125 & 54 & 11 & $6.7 \times 10^{4}(2.7)$ \\
\hline
\end{tabular}

[a] Reaction conditions: $4 \mu \mathrm{mol}$ catalyst precursor; initial ethylene pressure: $40 \mathrm{bar}$; temperature: $50^{\circ} \mathrm{C}$; reac tion time: $1 \mathrm{~h}$. [b] Measured at $50^{\circ} \mathrm{C}$ after loading the $10 \mathrm{~mL}$ reactor with 40 bar ethylene at room temperature and with $\mathrm{CO}_{2}$. [c] Average turnover number (mol[ethylene]/mol[Ni]); [d] Determined by DSC $\left(10^{\circ} \mathrm{Cmin}{ }^{-1}\right)$. [e] Enthalpy of $100 \%$ crystalline $\mathrm{PE}$ is $293 \mathrm{Jg}^{-1} \cdot{ }^{[35]}$ [f] Branches per 1000 carbon atoms determined by ${ }^{13} \mathrm{C}$ NMR; predominantly Me branches, but also Et and $\mathrm{C}_{4+}$ higher branches, see Figure S2 in Supporting Information. [g] Determined by GPC at $160^{\circ} \mathrm{C}$ in trichlorobenzene versus linear polyethylene standards. [h] Bimodal. [i] n.d.= not determined. branches $\left(\mathrm{C}_{4+}\right)$ is also detectable in some spectra (Figure S2 in the Supporting Information).

Based on these results, polymerisation with $\mathbf{6 c}$ was studied in more detail (Table 2). The effect of reaction temperature was studied (entries 1 to 3 ). At $30^{\circ} \mathrm{C}$, polymerisation is sluggish. At $70^{\circ} \mathrm{C}$, overall productivity is increased twofold versus polymerisation at $50^{\circ} \mathrm{C}$ This demonstrates that the cata- that these productivities are not limited by a complete consumption of ethylene, as the initial amount of ethylene in the reactor is $0.8-1 \mathrm{~g}$, corresponding to a substrate to nickel ratio of approximately $8 \times 10^{3}$. Catalyst precursor $6 \mathbf{e}$, which previously showed high activity in toluene and water, ${ }^{[22,36]}$ is also active in supercritical carbon dioxide as solvent. Complex 6d, which contains the largest number of $\mathrm{CO}_{2}$-philic groups, was found to be the least active probably due to fast decomposition of the catalyst, as evidenced by the yellowish colour of the reaction mixture, a typical indication for decomposition for these salicylaldimine complexes. The initial pressure of 40 bar ethylene at room temperature corresponds to an ethylene concentration of approximately $2.3 \mathrm{~mol} \mathrm{~L}^{-1}$. $^{[37]}$ This concentration corresponds to polymerisation experiments in toluene solution at about 27 atm (calculating the ethylene concentration with the data of Prausnitz et al.). ${ }^{[38]}$ Activities found for $6 \mathbf{e}$ in toluene at $50^{\circ} \mathrm{C}$ are $8 \times$ $10^{3} \mathrm{TONh}^{-1}$ at 5 bar and $4 \times 10^{4} \mathrm{TONh}^{-1}$ at 40 bar. $^{[22]}$ This indicates that productivities are somewhat lower in $\mathrm{scCO}_{2}$ by comparison to toluene at the same monomer concentration, but within the same order of magnitude. The lower productivity may be due to the lower solubility of the polymer in $\mathrm{scCO}_{2}$ as compared with toluene, resulting in precipitation of polymer and possible enclosure of catalyst at an early point, which can reduce catalyst activity. Another important difference is that the polymer will be less swollen with $\mathrm{CO}_{2}$ than with toluene, which may also contribute to a reduced overall rate.

For $\mathbf{6 c}$ and $\mathbf{6 e}$, which have also been studied in toluene as a reaction medium, the overall properties of the polyethylenes obtained in $\mathrm{scCO}_{2}$ and in toluene are similar (toluene; 40 bar ethylene pressure; $50^{\circ} \mathrm{C}$ polymerisation temperature; 6c: $M_{\mathrm{w}}=4.6 \times 10^{4} \mathrm{~g} \mathrm{~mol}^{-1} ; M_{\mathrm{w}} / M_{\mathrm{n}}=2.3 ; T_{\mathrm{m}}=111^{\circ} \mathrm{C} ; 45 \%$ crystallinity ${ }^{[26]} \mathbf{6 e}: M_{\mathrm{w}}=1.0 \times 10^{5} \mathrm{~g} \mathrm{~mol}^{-1} ; M_{\mathrm{w}} / M_{\mathrm{n}}=5.1 ; T_{\mathrm{m}}=$ $123^{\circ} \mathrm{C} ; 50 \%$ crystallinity $\left.{ }^{[22]}\right)$. Comparing the polymers prepared in $\mathrm{scCO}_{2}$ with the different catalyst precursors, branching and thus crystallinity can be varied over a substantial range through the substitution pattern of the salicylaldimine ligand (Table 1).

Analysis of polymer microstructures by ${ }^{13} \mathrm{C}$ NMR spectroscopy reveals that the polymers predominantly contain methyl branches; a small amount of ethyl and higher
Table 2. Polymerisation of ethylene in $\mathrm{scCO}_{2}$ with catalyst $\mathbf{6 c}$ : effect of density, temperature and surfactants. ${ }^{[\mathrm{a}]}$

\begin{tabular}{lllccll}
\hline & $\begin{array}{l}\rho\left(\mathrm{CO}_{2}\right) \\
{\left[\mathrm{g} \mathrm{mL}^{-1}\right]}\end{array}$ & $\begin{array}{l}T \\
{\left[{ }^{\circ} \mathrm{C}\right]}\end{array}$ & $\begin{array}{l}\text { Surfactant } \\
{[\mathrm{mg}]}\end{array}$ & $\mathrm{TON}^{[\mathrm{b}]}$ & $\begin{array}{l}T_{\mathrm{m}} \\
{\left[{ }^{\circ} \mathrm{C}\right]}\end{array}$ & $\begin{array}{l}M_{\mathrm{w}}\left(M_{\mathrm{w}} / M_{\mathrm{n}}\right) \\
{\left[\mathrm{g} \mathrm{mol}^{-1}\right]}\end{array}$ \\
\hline 1 & 1.02 & 30 & - & 446 & $114-124$ & $9.0 \times 10^{3}(1.3)$ \\
2 & 0.94 & 70 & - & 4706 & 119 & $1.9 \times 10^{4}(16)^{[\mathrm{g}]}$ \\
3 & 0.99 & 50 & - & 2015 & 125 & $6.5 \times 10^{4}(3.1)$ \\
4 & 0.73 & 50 & - & $88^{[\mathrm{c}]}$ & 108 & $4.1 \times 10^{4}(2.5)$ \\
5 & 0.43 & 50 & - & $179^{[\mathrm{c}]}$ & n.d..$^{[\mathrm{h}]}$ & n.d..$^{\mathrm{h}]}$ \\
6 & 0.99 & 50 & $25^{[\mathrm{d}]}$ & 670 & $107-119$ & $3.0 \times 10^{4}(4.8)$ \\
7 & 1.03 & 50 & $25^{[\mathrm{e}]}$ & 4914 & 122 & $6.9 \times 10^{4}(3.2)$ \\
8 & 1.00 & 50 & $90^{[\mathrm{f}]}$ & 2059 & 107 & $1.7 \times 10^{4}(2.5)$ \\
9 & 1.04 & 50 & $190^{[\mathrm{f}]}$ & 846 & 113 & $6.6 \times 10^{4}(3.0)$ \\
\hline
\end{tabular}

[a] Reaction conditions: $4 \mu \mathrm{mol}$ catalyst precursor $\mathbf{6 c} ; 10 \mathrm{~mL}$ reactor; initial ethylene pressure: $40 \mathrm{bar}$; reaction time: $1 \mathrm{~h}$. [b] Calculated from mass of polymer isolated, mass of surfactant is subtracted (mol[E]/ mol[Ni]). [c] Precipitation of the catalysts was observed. [d] Fluowet NMQ. [e] Fluowet PL80. [f] $\mathrm{CF}_{3}-\left(\mathrm{CF}_{2}\right)_{2}-\mathrm{CO}_{2}-\left(\mathrm{CH}_{2}\right)_{11}-\mathrm{CH}_{3}$. [g] Multimodal. $[\mathrm{h}]$ n.d. $=$ not determined.

lyst is quite temperature stable in $\mathrm{scCO}_{2}$. The narrow molecular weight distribution of the polymer obtained at $30^{\circ} \mathrm{C}$ (entry 1) indicates that the chain transfer rate is on the same order as the reaction time of $1 \mathrm{~h}$ at this temperature, and that living ethylene polymerisation in $\mathrm{CO}_{2}$ may be possible.

Increased branching occurs with increasing temperature, as expected, resulting in a lower melting temperature of the semicrystalline polyethylene (compare entry 2 with 3 ). A similar behaviour was found for catalyst precursor $6 \mathbf{e}$ in toluene. ${ }^{[22]}$

The effect of carbon dioxide density on activity was also studied (entries 3-5). For this purpose, the $10 \mathrm{~mL}$ reactor used was charged with different amounts of $\mathrm{CO}_{2}(4.3-9.9 \mathrm{~g}$, corresponding to a density of $\left.0.43-0.99 \mathrm{~g} \mathrm{~m} \mathrm{~L}^{-1}\right)$. As an overall trend, productivities decreased with decreasing density. This results at least partly from insufficient solubility of the catalyst precursor in the reaction medium at lower densities, which could be confirmed visually through the reactor windows (Table 2).

Precipitation of polyethylene in carbon dioxide occurs from the very beginning of the reaction, already at $35^{\circ} \mathrm{C}$, as seen through the reactor windows. It was therefore investigated whether appropriate surfactants with a $\mathrm{CO}_{2}$-philic and a $\mathrm{CO}_{2}$-phobic moiety that can interact with the polyethylene 
particles may influence polymer particle formation and polymer morphologies. ${ }^{[5]}$ To this end, preliminary experiments were carried out in the presence of Fluowet NMQ (cationic fluorinated quaternary ammonium salt, see Figure S4 in the Supporting Information), Fluowet PL80 (mixture of perfluorinated phosphinic and phosphonic acid), and perfluorobutyric acid dodecyl ester. All compounds were found to be compatible with the catalyst and no significant deactivation occurred. The presence of the surfactants affects the outcome of the polymerisation reaction in terms of polymer molecular weight, yield and crystallinity (Table 2, entries 69 ), but no general trends can be derived from the data so far.

The surface morphology of the polyethylene particles formed was studied by transmission electron microscopy (TEM). In the absence of surfactants, large irregular-shaped polyethylene particles are obtained (Figure 1, left). The presence of the cationic surfactant Fluowet NMQ and the neutral perfluorobutyric acid dodecyl ester appears to result in somewhat smaller and more compact particles with needle-like structures on their surface (Figure 1 middle and right).

\section{Summary and Conclusions}

Ethylene can be polymerised in a precipitation polymerisation process by using $\mathrm{scCO}_{2}$ as a reaction medium with neutral $\mathrm{Ni}^{\mathrm{II}}$ complexes as catalysts. Semicrystalline polyethylene is obtained. The branching structure, and thus the crystallinity of the polymer can be altered through variation of the catalyst and the reaction conditions employed. This differs from a previous report on ethylene polymerisation with a cationic Pd-diimine complex, which invariably affords highly branched amorphous polyethylene with a given overall degree of branching. ${ }^{[19 b]}$ Catalyst precursors soluble in the reaction medium are required for high catalyst activities. A series of nickel(II)-salicylaldiminato complexes with various substitution patterns of perfluorooctyl and trifluoromethylgroups was prepared. Solubility in $\mathrm{scCO}_{2}$ increases not only with increasing fluorine content, but also with the number of fluorine-containing moieties. Complex $\mathbf{6 c}$, with eight trifluoromethyl groups, is well soluble in $\mathrm{scCO}_{2}$. A comparison with toluene as a reaction medium indicates that catalyst productivities are slightly lower in $\mathrm{scCO}_{2}$ under comparable conditions. The presence of surfactants appears to alter polymer morphologies on a micron scale.

\section{Experimental Section}

General procedures and materials: All reactions were carried out by using standard Schlenk techniques under an argon atmosphere. Solvents were distilled and deoxygenated prior to use. Ethylene ( 2.5 grade) and carbon dioxide (5.5 grade) supplied by Praxair were used without further purification. [Ni(tmeda)(Me $)_{2}$ ] was supplied by MCat (Konstanz). 4-(Trifluoromethyl)phenylboronic $\quad \operatorname{acid}^{[39]} \quad\left(\mathbf{2}^{\prime}\right), \quad 6-\mathrm{C}(\mathrm{H})=\mathrm{O}-2,4-\{3,5-$ $\left.\left(\mathrm{F}_{3} \mathrm{C}\right)_{2} \mathrm{C}_{6} \mathrm{H}_{3}\right\}_{2} \mathrm{C}_{6} \mathrm{H}_{2} \mathrm{OH}\left(\mathbf{4}^{\prime}\right),{ }^{[26]}$ and $6-\mathrm{C}(\mathrm{H})=\mathrm{N}\left[2,6-\left\{3,5-\left(\mathrm{F}_{3} \mathrm{C}\right)_{2} \mathrm{C}_{6} \mathrm{H}_{3}\right\}_{2} \mathrm{C}_{6} \mathrm{H}_{3}\right]-$ $2,4-\left\{3,5-\left(\mathrm{F}_{3} \mathrm{C}\right)_{2} \mathrm{C}_{6} \mathrm{H}_{3}\right\}_{2} \mathrm{C}_{6} \mathrm{H}_{2} \mathrm{OH}(\mathbf{5} \mathbf{c}),{ }^{[26]}$ and complexes $\mathbf{6} \mathbf{c}^{[26]}$ and $\mathbf{6} \mathbf{e}^{[22]}$ were prepared according to known procedures. Perfluorinated surfactants FLUOWET NMQ and Fluowet PL80 were provided by Clariant GmbH.

${ }^{1} \mathrm{H}$ and ${ }^{13} \mathrm{C}$ NMR spectra were recorded on either a Bruker ARX 300, a Bruker Avance DRX 600 or a Varian Inova 400 spectrometer. ${ }^{1} \mathrm{H}$ and ${ }^{13} \mathrm{C}$ chemical shifts were referenced to solvent signals. Assignments were made from NOE, gCOSY and gHMQC experiments (for numbering of atoms see Scheme 4). High-temperature NMR spectroscopy for polyethylene characterisation was performed in $\left[D_{2}\right] 1,1,2,2$-tetrachloroethane at $100^{\circ} \mathrm{C}$. Elemental analyses were carried out on a Elementar Vario EL Instrument at Freiburg University. Mass spectra were obtained with a Thermoelectron TSQ-7000 mass spectrometer at Freiburg University. Differential scanning calorimetry (DSC) was performed on a Netzsch DSC 204 $\mathrm{F} 1$ at a heating rate of $10 \mathrm{~K} \mathrm{~min}^{-1}$. DSC data reported are from second heating cycles. Molecular weight determination was carried out with a PL GPC-220 instrument using a Mixed B column in trichlorobenzene at $160^{\circ} \mathrm{C}$ versus polyethylene standards.

1-Bromo-4-(perfluorooctyl)benzene (1): 4-Bromophenyliodide was treated with $\mathrm{C}_{8} \mathrm{~F}_{17} \mathrm{I}$ in the presence of copper following a reported procedure. ${ }^{[2]}$ Yield: $79 \% .{ }^{1} \mathrm{H}$ NMR (300 MHz, $\left.\mathrm{CDCl}_{3}, \mathrm{RT}\right): \delta=7.66\left(\mathrm{~d},{ }^{3} J=\right.$ $9 \mathrm{~Hz}, 2 \mathrm{H} ; \mathrm{CH}), 7.46 \mathrm{ppm}\left(\mathrm{d},{ }^{3} \mathrm{~J}=9 \mathrm{~Hz}, 2 \mathrm{H} ; \mathrm{CH}\right) ;{ }^{13} \mathrm{C} \mathrm{NMR}(75.4 \mathrm{MHz}$, $\left.\mathrm{CDCl}_{3}, \mathrm{RT}\right): \delta=132.3(\mathrm{CH}), 128.7(\mathrm{CH}), 128.4\left(\mathrm{C}-\mathrm{R}^{\mathrm{F}}\right), 127.3(\mathrm{C}-\mathrm{Br})$, 119.4-106.9 ppm (overlapped $\mathrm{R}^{\mathrm{F}}$ signals); ${ }^{19} \mathrm{~F} \mathrm{NMR}\left(376.5 \mathrm{MHz}, \mathrm{CDCl}_{3}\right.$, $\mathrm{RT}): \delta=-81.3\left(\mathrm{CF}_{3}\right),-111.5\left(\mathrm{CF}_{2}\right),-121.7\left(\mathrm{CF}_{2}\right),-122.4\left(3 \mathrm{CF}_{2}\right)$, $-123.3\left(\mathrm{CF}_{2}\right), \quad-126.7 \mathrm{ppm}\left(\mathrm{CF}_{2}\right) ; \mathrm{MS}(\mathrm{EI}): \mathrm{m} / \mathrm{z}: 574[\mathrm{M}]^{+}, 205$ $\left[M-\mathrm{C}_{7} \mathrm{~F}_{15}\right]^{+}$.

4-(Perfluorooctyl)phenylboronic acid (2): $\mathrm{BuLi}(9.6 \mathrm{mmol})$ was added dropwise at $-78^{\circ} \mathrm{C}$ to a solution of $\mathbf{1}(5 \mathrm{~g}, 8.7 \mathrm{mmol})$ in $\mathrm{Et}_{2} \mathrm{O}(25 \mathrm{~mL})$ and stirred for an hour. After this time $\mathrm{B}(\mathrm{OEt})_{3}(9.6 \mathrm{mmol})$ was added dropwise at $-78^{\circ} \mathrm{C}$ and the mixture stirred for $1.5 \mathrm{~h}$. Acidic hydrolysis of the boronic ester, and extraction from the aqueous mixture with $\mathrm{Et}_{2} \mathrm{O}$ yielded the product as a white solid. Yield: $85 \% .{ }^{1} \mathrm{H}$ NMR $(300 \mathrm{MHz}$,

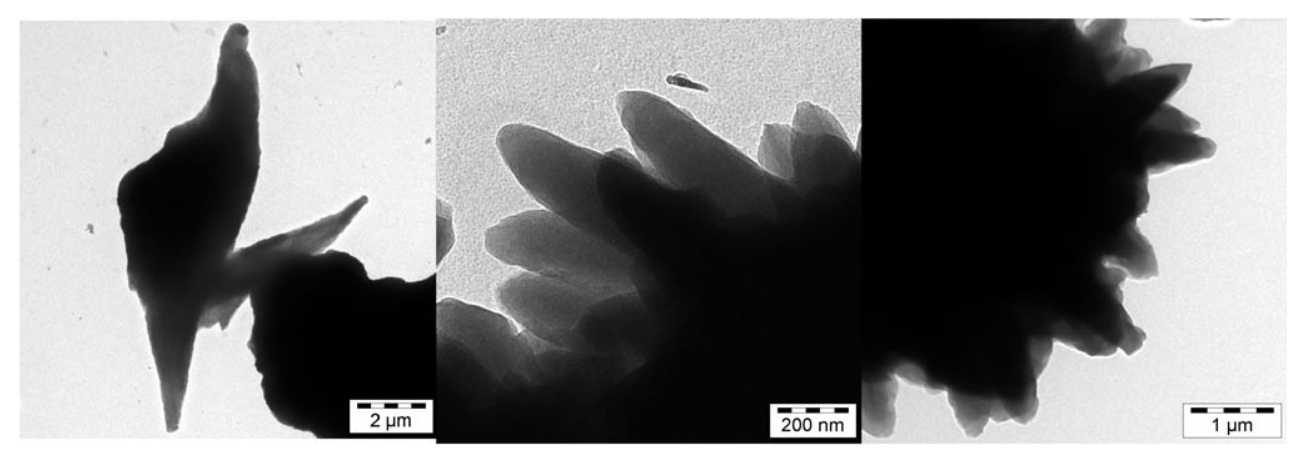

Figure 1. TEM micrographs of polyethylene obtained with precursor $6 \mathbf{c}$ at $50^{\circ} \mathrm{C}$; in the absence of surfactant (left), in the presence of FLUOWET NMQ (middle), and in the presence of $\mathrm{CF}_{3}-\left(\mathrm{CF}_{2}\right)_{2}-\mathrm{CO}_{2}-\left(\mathrm{CH}_{2}\right)_{11}-\mathrm{CH}_{3}$ (right). 
[D $\mathrm{D}_{6}$ ]acetone, RT): $\delta=8.40\left(\mathrm{~d},{ }^{3} J=8.3 \mathrm{~Hz}, 2 \mathrm{H}\right), 8.20 \mathrm{ppm}\left(\mathrm{d},{ }^{3} J=8.3 \mathrm{~Hz}\right.$, $2 \mathrm{H}) ;{ }^{13} \mathrm{C}$ NMR (75.4 MHz, [D 6 ]acetone, RT): $\delta=136.7(\mathrm{CH}), 131.8,127.9$ $(\mathrm{CH}), 113.7 \mathrm{ppm} ;{ }^{19} \mathrm{~F}$ NMR $\left(282.4 \mathrm{MHz},\left[\mathrm{D}_{6}\right]\right.$ acetone, RT): $\delta=-80.9$ $\left(\mathrm{CF}_{3}\right),-110.8\left(\mathrm{CF}_{2}\right),-121.0\left(\mathrm{CF}_{2}\right),-121.7 \quad\left(3 \mathrm{CF}_{2}\right),-122.6 \quad\left(\mathrm{CF}_{2}\right)$, $-126.1 \mathrm{ppm}\left(\mathrm{CF}_{2}\right)$

Synthesis of 2,6-disubstituted anilines: The corresponding aryl boronic acid $(3.16 \mathrm{mmol})$ in EtOH $(3 \mathrm{~mL})$ and an aqueous $\mathrm{Na}_{2} \mathrm{CO}_{3}$ solution $(2 \mathrm{M}$, $5 \mathrm{~mL})$ were added to 2,6-dibromoaniline $(0.38 \mathrm{~g}, 1.5 \mathrm{mmol})$ in toluene $(15 \mathrm{~mL})$, and the mixture was degassed. $\left[\mathrm{Pd}\left(\mathrm{PPh}_{3}\right)_{4}\right](0.15 \mathrm{mmol})$ was added and the reaction mixture was heated to $96^{\circ} \mathrm{C}$ and stirred for $24 \mathrm{~h}$. The aqueous phase was separated and extracted with $\mathrm{Et}_{2} \mathrm{O}$. The solvent was removed from the organic phases by evaporation under reduced pressure, and the product was purified by chromatography on silica.

2,6-Di-(4-perfluorooctyl)phenylaniline (3): Yield: $85 \% . \quad R_{\mathrm{f}}=0.47$ (hexane); ${ }^{1} \mathrm{H}$ NMR (300 MHz, $\left.\mathrm{CDCl}_{3}, \mathrm{RT}\right): \delta=7.68\left(\mathrm{~m}, 8 \mathrm{H} ; \mathrm{H}^{8}, \mathrm{H}^{9}\right)$, $7.16\left(\mathrm{~d},{ }^{3} \mathrm{~J}=7.7 \mathrm{~Hz}, 2 \mathrm{H} ; \mathrm{H}^{3}, \mathrm{H}^{5}\right), 6.93\left(\mathrm{t},{ }^{3} \mathrm{~J}=7.7 \mathrm{~Hz}, 1 \mathrm{H} ; \mathrm{H}^{4}\right), 3.80 \mathrm{ppm}$ (br, 2H; $\mathrm{NH}_{2}$ ); ${ }^{13} \mathrm{C}$ NMR (75.4 MHz, $\left.\mathrm{CDCl}_{3}, \mathrm{RT}\right): \delta=143.7\left(\mathrm{~s}, \mathrm{C}^{1}\right), 140.7$ $\left(\mathrm{s}, \mathrm{C}^{10}\right), 130.6\left(\mathrm{~s}, \mathrm{C}^{3}, \mathrm{C}^{5}\right), 129.8\left(\mathrm{~s}, \mathrm{C}^{8}\right.$ or $\left.\mathrm{C}^{9}\right), 127.7\left(\mathrm{~s}, \mathrm{C}^{2}, \mathrm{C}^{6}, \mathrm{C}^{7}\right), 126.8(\mathrm{~s}$, $\mathrm{C}^{9}$ or $\left.\mathrm{C}^{8}\right), 118.9\left(\mathrm{~s}, \mathrm{C}^{4}\right), 116.1(\mathrm{~m}, \mathrm{CF}), 111.7$ (m, CF), $107.1 \mathrm{ppm}(\mathrm{m}, \mathrm{CF})$; ${ }^{19} \mathrm{~F}$ NMR $\left(282.4 \mathrm{MHz}, \mathrm{CDCl}_{3}, \mathrm{RT}\right): \delta=-80.8\left(\mathrm{CF}_{3}\right),-110.6 \quad\left(\mathrm{CF}_{2}\right)$, $-121.3\left(\mathrm{CF}_{2}\right),-121.7\left(\mathrm{CF}_{2}\right),-121.9\left(2 \mathrm{CF}_{2}\right),-122.7\left(\mathrm{CF}_{2}\right),-126.5 \mathrm{ppm}$ $\left(\mathrm{CF}_{2}\right)$; $\mathrm{MS}(\mathrm{CI}): m / z: 1082[\mathrm{M}]^{+}$

2,6-Di-(4-trifluoromethyl)phenylaniline $\left(\mathbf{3}^{\prime}\right)$ : Yield: $56 \% . R_{\mathrm{f}}=0.93$ (toluene); ${ }^{1} \mathrm{H}$ NMR (300 MHz, $\left.\mathrm{CDCl}_{3}, \mathrm{RT}\right): \delta=7.74\left(\mathrm{~m}, 4 \mathrm{H} ; \mathrm{H}^{9}\right), 7.65(\mathrm{~m}$, $\left.4 \mathrm{H} ; \mathrm{H}^{8}\right), 7.15\left(\mathrm{~d},{ }^{3} J=7.5 \mathrm{~Hz}, 2 \mathrm{H} ; \mathrm{H}^{3}, \mathrm{H}^{5}\right), 6.93\left(\mathrm{t},{ }^{3} J=7.5 \mathrm{~Hz}, 1 \mathrm{H} ; \mathrm{H}^{4}\right)$, 3.79 ppm (br, $2 \mathrm{H} ; \mathrm{NH}_{2}$ ); ${ }^{13} \mathrm{C}$ NMR (75.4 MHz, $\left.\mathrm{CDCl}_{3}, \mathrm{RT}\right): \delta=143.4$ (s, $\left.\mathrm{C}^{1}\right), 140.7\left(\mathrm{~s}, \mathrm{C}^{10}\right), 130.7\left(\mathrm{~s}, \mathrm{C}^{3}, \mathrm{C}^{5}\right), 129.6\left(\mathrm{~s}, \mathrm{C}^{8}\right), 129.2\left(\mathrm{~m}, \mathrm{CF}_{3}\right), 126.9(\mathrm{~s}$, $\left.\mathrm{C}^{7}\right), \quad 126.1 \quad\left(\mathrm{~s}, \quad \mathrm{C}^{2}, \mathrm{C}^{6}\right), 125.7 \quad\left(\mathrm{~s}, \mathrm{C}^{9}\right), \quad 118.8 \mathrm{ppm} \quad\left(\mathrm{s}, \mathrm{C}^{4}\right) ;{ }^{19} \mathrm{~F} \mathrm{NMR}$ $\left(282.4 \mathrm{MHz}, \mathrm{CDCl}_{3}, \mathrm{RT}\right): \delta=-63.0 \mathrm{ppm}\left(\mathrm{CF}_{3}\right) ; \mathrm{MS}(\mathrm{EI}): \mathrm{m} / \mathrm{z}: 381[\mathrm{M}]^{+}$, $235\left[M-\mathrm{C}_{7} \mathrm{H}_{4} \mathrm{~F}_{3}\right]^{2+}, 167\left[M-\mathrm{C}_{7} \mathrm{H}_{4} \mathrm{~F}_{3}-\mathrm{CF}_{3}\right]^{2+}$

Synthesis of salicylaldimines: The corresponding aniline $(1.16 \mathrm{mmol})$ (for aniline 3 dissolved in (trifluoromethyl)undecafluorocyclohexane $(3 \mathrm{~mL})$ ) and a catalytic amount of formic acid were added to a solution of 3,5diiodosalicylaldehyde (4) or aldehyde $4^{\prime}(1.27 \mathrm{mmol})$ in $\mathrm{MeOH}(4 \mathrm{~mL})$, and the mixture heated overnight at reflux. The precipitated imine was isolated by filtration and washed with cold methanol.

Data for 5a: Yield: $70 \% ;{ }^{1} \mathrm{H}$ NMR $\left(300 \mathrm{MHz}, \mathrm{CDCl}_{3}, \mathrm{RT}\right): \delta=8.00(\mathrm{~d}$, ${ }^{4} J=2.1 \mathrm{~Hz}, 1 \mathrm{H}$; CH-CI), $7.71(\mathrm{~s}, 1 \mathrm{H} ; \mathrm{N}=\mathrm{CH}), 7.60\left(\mathrm{~d},{ }^{3} \mathrm{~J}=8.4 \mathrm{~Hz}, 4 \mathrm{H}\right.$; $\left.\mathrm{H}^{8}\right), 7.47\left(\mathrm{~m}, 7 \mathrm{H} ; \mathrm{H}^{3}, \mathrm{H}^{4}, \mathrm{H}^{5}, \mathrm{H}^{9}\right), 7.04 \mathrm{ppm}\left(\mathrm{d},{ }^{4} \mathrm{~J}=2.1 \mathrm{~Hz}, 1 \mathrm{H} ; \mathrm{CH}-\mathrm{CI}\right)$; ${ }^{13} \mathrm{C} \mathrm{NMR}\left(75.4 \mathrm{MHz}, \mathrm{CDCl}_{3}, \mathrm{RT}\right): \delta=167.2(\mathrm{~s}, \mathrm{~N}=\mathrm{C}), 159.8(\mathrm{~s}, \mathrm{C}-\mathrm{OH})$, 150.0 (s, CH-CI), 144.3 (s, $\mathrm{C}^{1}$ ), 143.0, 140.4 (s, CH-CI), $134.0\left(\mathrm{~s}, \mathrm{C}^{8}\right.$ or $\mathrm{C}^{9}$ ), 131.2, $130.1\left(\mathrm{~s}, \mathrm{C}^{9}\right.$ or $\left.\mathrm{C}^{8}\right), 129.8-127.0\left(\mathrm{~m}, \mathrm{C}^{10}, \mathrm{C}^{4}, \mathrm{C}-\mathrm{F}\right), 119.9,87.0(\mathrm{~s}, \mathrm{C}-$ I), $80.1 \mathrm{ppm}(\mathrm{s}, \mathrm{C}-\mathrm{I}) ;{ }^{19} \mathrm{~F}$ NMR $\left(282.4 \mathrm{MHz}, \mathrm{CDCl}_{3}, \mathrm{RT}\right): \delta=-81.1\left(\mathrm{CF}_{3}\right)$, $-111.2 \quad\left(\mathrm{CF}_{2}\right), \quad-121.6 \quad\left(\mathrm{CF}_{2}\right),-122.0 \quad\left(\mathrm{br}, \quad 2 \mathrm{CF}_{2}\right),-123.1 \quad\left(\mathrm{CF}_{2}\right)$, $-126.5 \mathrm{ppm}\left(\mathrm{CF}_{2}\right)$; $\mathrm{MS}(\mathrm{EI}): \mathrm{m} / \mathrm{z}: 1437[\mathrm{M}]^{+}$.

Data for 5b: Yield: $61 \%$; ${ }^{1} \mathrm{H}$ NMR $\left(300 \mathrm{MHz}, \mathrm{C}_{6} \mathrm{D}_{6}, \mathrm{RT}\right): \delta=13.6$ (s, $1 \mathrm{H} ; \mathrm{OH}), 7.87\left(\mathrm{~d},{ }^{4} J=2.1 \mathrm{~Hz}, 1 \mathrm{H} ; \mathrm{CH}-\mathrm{CI}\right), 7.44\left(\mathrm{~d},{ }^{3} J=8.1 \mathrm{~Hz}, 4 \mathrm{H} ; \mathrm{H}^{9}\right.$ or $\left.\mathrm{H}^{8}\right), 7.35(\mathrm{~s}, 1 \mathrm{H} ; \mathrm{N}=\mathrm{CH}), 7.23\left(\mathrm{~m}, 7 \mathrm{H} ; \mathrm{H}^{3}, \mathrm{H}^{4}, \mathrm{H}^{5}\right.$, and $\mathrm{H}^{9}$ or $\left.\mathrm{H}^{8}\right)$, $6.78 \mathrm{ppm}\left(\mathrm{d},{ }^{4} \mathrm{~J}=2.1 \mathrm{~Hz}, 1 \mathrm{H} ; \mathrm{CH}-\mathrm{CI}\right) ;{ }^{13} \mathrm{C} \mathrm{NMR}\left(75.4 \mathrm{MHz}, \mathrm{C}_{6} \mathrm{D}_{6}, \mathrm{RT}\right)$ : $\delta=167.5(\mathrm{~s}, \mathrm{~N}=\mathrm{C}), 160.1(\mathrm{~s}, \mathrm{C}-\mathrm{OH}), 150.2(\mathrm{~s}, \mathrm{CH}-\mathrm{CI}), 144.6\left(\mathrm{~s}, \mathrm{C}_{1}\right), 142.8$, 140.3 (s, CH-CI), $134.0\left(\mathrm{~s}, \mathrm{C}^{2}, \mathrm{C}^{6}\right), 131.1,130.2\left(\mathrm{~s}, \mathrm{C}^{8}, \mathrm{C}^{9}\right), 126.7\left(\mathrm{~s}, \mathrm{C}^{4}\right)$, $125.8\left(\mathrm{~m}, \mathrm{C}^{10}\right), 120.0\left(\mathrm{~s}, \mathrm{C}^{12}\right), 87.7$ (s, C-I), $80.5 \mathrm{ppm}(\mathrm{s}, \mathrm{C}-\mathrm{I}) ;{ }^{19} \mathrm{~F} \mathrm{NMR}$ (282.4 MHz, $\left.\mathrm{C}_{6} \mathrm{D}_{6}, \mathrm{RT}\right): \delta=-62.6 \mathrm{ppm}\left(\mathrm{CF}_{3}\right)$; MS (EI): $\mathrm{m} / z: 737[\mathrm{M}]^{+}$, $392.2\left[M-\mathrm{C}_{6} \mathrm{H}_{3} \mathrm{OI}_{2}\right]^{+}$; elemental analysis calcd (\%) for $\mathrm{C}_{27} \mathrm{H}_{15} \mathrm{~F}_{6} \mathrm{I}_{2} \mathrm{NO}$ (737.2): C 43.99, H 2.05, N 1.90; found: C 43.98, H 1.80, N 1.73.

Data for 5d: Yield: $76 \%$; ${ }^{1} \mathrm{H}$ NMR $\left(400 \mathrm{MHz}, \mathrm{CDCl}_{3}, \mathrm{RT}\right): \delta=13.2$ (br, $\mathrm{OH}), 8.05$ (s, $1 \mathrm{H} ; \mathrm{N}=\mathrm{CH}), 8.01(\mathrm{br}, 2 \mathrm{H} ; \mathrm{CH}), 7.89$ (br, $1 \mathrm{H} ; \mathrm{CH}), 7.81$ (br, $3 \mathrm{H} ; \mathrm{CH}), 7.62\left(\mathrm{~d},{ }^{3} J=8.2 \mathrm{~Hz}, 4 \mathrm{H} ; \mathrm{H}^{8}\right), 7.56\left(\mathrm{~d},{ }^{3} J=8.2 \mathrm{~Hz}, 4 \mathrm{H} ; \mathrm{H}^{9}\right)$, $7.57\left(\mathrm{~d},{ }^{4} J=2.0 \mathrm{~Hz}, 1 \mathrm{H} ; \mathrm{H}^{15}\right.$ or $\left.\mathrm{H}^{17}\right), 7.51\left(\mathrm{~m}, 3 \mathrm{H} ; \mathrm{H}^{3}, \mathrm{H}^{4}, \mathrm{H}^{5}\right), 7.05 \mathrm{ppm}$ $\left(\mathrm{d},{ }^{4} \mathrm{~J}=2.0 \mathrm{~Hz}, 1 \mathrm{H} ; \mathrm{H}^{15}\right.$ or $\left.\mathrm{H}^{17}\right) ;{ }^{13} \mathrm{C} \mathrm{NMR}\left(100.5 \mathrm{MHz}, \mathrm{CDCl}_{3}, \mathrm{RT}\right): \delta=$ $168.8(\mathrm{~s}, \mathrm{C}=\mathrm{N}), 158.8(\mathrm{~s}, \mathrm{C}-\mathrm{OH}), 144.5\left(\mathrm{~s}, \mathrm{C}^{1}\right), 144.5,143.2,141.6,140.7$, 138.6, $134.1\left(\mathrm{~s}, \mathrm{C}^{2}, \mathrm{C}^{6}\right), 132.9,132.8,132.3\left(\mathrm{q},{ }^{1} J(\mathrm{C}, \mathrm{F})=142 \mathrm{~Hz}, \mathrm{CF}_{3}\right)$, 131.1, 130.6, $130.2\left(\mathrm{~s}, \mathrm{C}^{8}\right.$ or $\left.\mathrm{C}^{9}\right), 130.0,129.8$ (s, $\mathrm{C}^{9}$ or $\left.\mathrm{C}^{8}\right), 129.7$ (br, CF), 128.3, 128.2, 127.7 (m, CF), $127.4(\mathrm{~m}, \mathrm{CF}), 127.1$ (s, $\left.\mathrm{C}^{4}\right), 126.9,124.9$, 124.7, 122.2, 122.0, 121.6 (m, CF), 121.2 (m, CF), $119.3\left(\mathrm{~s}, \mathrm{C}^{12}\right)$, $118.9 \mathrm{ppm}$; MS (EI): $\mathrm{m} / \mathrm{z}: 1608.5[\mathrm{M}]^{+}$
Synthesis of complexes $6 \mathbf{a}, 6 \mathrm{~b}$ and $6 \mathrm{~d}$ : The corresponding salicylaldimine $(0.49 \mathrm{mmol})$ followed by pyridine $(0.5 \mathrm{~mL})$ were added to a solution of $\left[\mathrm{Ni}(\mathrm{tmeda})(\mathrm{Me})_{2}\right]^{[31]}(100 \mathrm{mg}, 0.49 \mathrm{mmol})$ in diethyl ether $(10 \mathrm{~mL})$ at $-30^{\circ} \mathrm{C}$. Instantaneously, an orange-red solution formed and an orangered precipitate appeared. The reaction mixture was stirred for $2 \mathrm{~h}$ at $-30^{\circ} \mathrm{C}$. The solvent was removed at reduced pressure, and the solid obtained was washed with cold pentane affording the neutral methylnickel(II) complexes.

Data for 6a: Yield: $68 \% ;{ }^{1} \mathrm{H}$ NMR $\left(400 \mathrm{MHz}, \mathrm{C}_{6} \mathrm{D}_{6}, \mathrm{RT}\right): \delta=8.15(\mathrm{br}$, $2 \mathrm{H}$; py), 7.95 (d, ${ }^{4} J=2 \mathrm{~Hz}, 1 \mathrm{H}$; $\left.\mathrm{CH}-\mathrm{CI}\right), 7.59$ (d, ${ }^{3} J=8.2 \mathrm{~Hz}, 4 \mathrm{H} ; \mathrm{H}^{9}$ or $\left.\mathrm{H}^{8}\right), 7.45\left(\mathrm{~d},{ }^{3} \mathrm{~J}=8.2 \mathrm{~Hz}, 4 \mathrm{H} ; \mathrm{H}^{8}\right.$ or $\left.\mathrm{H}^{9}\right), 7.14$ (overlapped with solvent, $\left.\mathrm{H}^{3}, \mathrm{H}^{5}\right), 7.05\left(\mathrm{~m}, 1 \mathrm{H} ; \mathrm{H}^{4}\right), 6.80(\mathrm{~s}, 1 \mathrm{H} ; \mathrm{N}=\mathrm{CH}), 6.77\left(\mathrm{~d},{ }^{4} J=2 \mathrm{~Hz}, 1 \mathrm{H}\right.$; CH-CI), 6.69 (br, $1 \mathrm{H}$; py), 6.41 (br, 2H; py), -0.72 ppm (s, 3H; Ni-Me); ${ }^{13} \mathrm{C}$ NMR $\left(100.5 \mathrm{MHz}, \mathrm{CDCl}_{3}, \mathrm{RT}\right): 168.0(\mathrm{~s}, C=\mathrm{N}), 163.9$ (s, CO-Ni), $151.5\left(\mathrm{br}, \mathrm{CH}^{\mathrm{py}}\right), 150.1,149.9$ (s, CH-CI), 143.8, 141.7 (s, CH-CI), 136.3 (br, $\left.\mathrm{CH}^{\mathrm{py}}\right), 134.9,131.0\left(\mathrm{~s}, \mathrm{C}^{3}+\mathrm{C}^{5}+\mathrm{C}^{8}\right.$ or $\left.\mathrm{C}^{9}\right), 128\left(\mathrm{C}^{4}\right.$ overlapped with solvent), $127.4\left(\mathrm{~s}, \mathrm{C}^{9}\right.$ or $\left.\mathrm{C}^{8}\right), 126.8,123.2\left(\mathrm{br}, \mathrm{CH}^{\mathrm{py}}\right), 120.7\left(\mathrm{~s}, \mathrm{C}^{12}\right), 97.5$ (s, CI), 72.5 (s, CI ), -7.9 ppm (s, Ni-CH 3$) ;{ }^{19} \mathrm{~F}$ NMR $\left(282.4 \mathrm{MHz}, \mathrm{C}_{6} \mathrm{D}_{6}, \mathrm{RT}\right)$ : -81.1 $\left(\mathrm{CF}_{3}\right),-110.9\left(\mathrm{CF}_{2}\right),-121.6\left(\mathrm{CF}_{2}\right),-122.2\left(3 \mathrm{CF}_{2}\right),-123.1\left(\mathrm{CF}_{2}\right)$, $-126.5 \mathrm{ppm}\left(\mathrm{CF}_{2}\right)$; no satisfactory elemental analysis was obtained as the high fluorine content disturbed the analysis.

Data for 6b: Yield: $88 \% ;{ }^{1} \mathrm{H}$ NMR $\left(400 \mathrm{MHz}, \mathrm{C}_{6} \mathrm{D}_{6}, \mathrm{RT}\right): \delta=8.13$ (br, $2 \mathrm{H}$; py), 7.92 (d, $\left.{ }^{4} J=2.4 \mathrm{~Hz}, 1 \mathrm{H} ; \mathrm{CH}-\mathrm{CI}\right), 7.54\left(\mathrm{~d},{ }^{3} J=8.2 \mathrm{~Hz}, 4 \mathrm{H} ; \mathrm{H}^{8}\right)$, $7.43\left(\mathrm{~d},{ }^{3} J=8.2 \mathrm{~Hz}, 4 \mathrm{H} ; \mathrm{H}^{9}\right), 7.13\left(\mathrm{~d},{ }^{3} J=7.6 \mathrm{~Hz}, 2 \mathrm{H} ; \mathrm{H}^{3}, \mathrm{H}^{5}\right), 7.06(\mathrm{t}$, $\left.{ }^{3} J=7.6 \mathrm{~Hz}, 1 \mathrm{H} ; \mathrm{H}^{4}\right), 6.82(\mathrm{~s}, 1 \mathrm{H} ; \mathrm{N}=\mathrm{CH}), 6.79\left(\mathrm{~d},{ }^{4} \mathrm{~J}=2.4 \mathrm{~Hz}, 1 \mathrm{H} ; \mathrm{CH}-\right.$ CI), 6.63 (br, $1 \mathrm{H}$; py), 6.39 (br, $2 \mathrm{H}$; py), $-0.73 \mathrm{ppm}$ (s, 3H; Ni-Me); ${ }^{13} \mathrm{C}$ NMR (100.5 MHz, C $\left.\mathrm{D}_{6}, \mathrm{RT}\right): 167.9(\mathrm{~s}, \mathrm{C}=\mathrm{N}), 163.8(\mathrm{~s}, \mathrm{CO}-\mathrm{Ni}), 151.4$ (br, $\left.\mathrm{CH}^{\mathrm{py}}\right), 150.2,149.9$ (s, CH-CI), 143.5, 141.8(s, CH-CI), 136.2 (br, $\left.\mathrm{CH}^{\mathrm{py}}\right), 135.1,131.0\left(\mathrm{C}^{8}, \mathrm{C}^{9}\right), 130.3,129.9,129.7\left(\mathrm{q},{ }^{2} J_{\mathrm{C}-\mathrm{F}}=33 \mathrm{~Hz}, \mathrm{C}^{10}\right)$, $129.6\left(\mathrm{~s}, \mathrm{C}^{4}\right), 126.7\left(\mathrm{~s}, \mathrm{C}^{3}+\mathrm{C}^{5}\right), 126.3,125.7\left(\mathrm{~m}, \mathrm{CF}_{3}\right), 123.6,123.2$ (br, $\left.\mathrm{CH}^{\mathrm{py}}\right), 120.7\left(\mathrm{~s}, \mathrm{C}^{12}\right), 97.7$ (s, CI), 72.7 (s, CI), -7.87 ppm (s, Ni-Me); elemental analysis calcd (\%) for $\mathrm{NiC}_{33} \mathrm{H}_{22} \mathrm{~F}_{6} \mathrm{I}_{2} \mathrm{~N}_{2} \mathrm{O}$ (889.0): C 44.59, H 2.49, N 3.15; found: C 43.98, H 2.71, N 3.39.

Data for 6d: Yield: $71 \% ;{ }^{1} \mathrm{H}$ NMR $\left(400 \mathrm{MHz}, \mathrm{C}_{6} \mathrm{D}_{6}, \mathrm{RT}\right): \delta=7.78$ (br, $4 \mathrm{H}$; $\mathrm{CH}$, py), 7.73 (br, $1 \mathrm{H} ; \mathrm{CH}), 7.67\left(\mathrm{~d},{ }^{3} \mathrm{~J}=8.4 \mathrm{~Hz}, 4 \mathrm{H} ; \mathrm{H}^{9}\right.$ or $\left.\mathrm{H}^{8}\right), 7.60$ (br, $1 \mathrm{H} ; \mathrm{CH}), 7.54\left(\mathrm{~m}, 6 \mathrm{H} ; \mathrm{H}^{9}\right.$ or $\mathrm{H}^{8}$ and $\left.\mathrm{CH}\right), 7.16\left(\mathrm{~N}=\mathrm{CH}\right.$ and $\mathrm{H}^{15}$ or $\mathrm{H}^{17}$ overlapped with solvent signal), $7.13\left(\mathrm{~m}, 3 \mathrm{H} ; \mathrm{H}^{3}, \mathrm{H}^{4}, \mathrm{H}^{5}\right), 6.70(\mathrm{~d}$, ${ }^{4} J=2.4 \mathrm{~Hz}, 1 \mathrm{H} ; \mathrm{H}^{15}$ or $\left.\mathrm{H}^{17}\right), 6.68(\mathrm{~m}, 1 \mathrm{H} ;$ py), $6.24(\mathrm{~m}, 2 \mathrm{H} ;$ py), $-0.76 \mathrm{ppm}$ (s, 3H; Ni-Me); ${ }^{13} \mathrm{C}$ NMR (100.5 MHz, $\left.\mathrm{C}_{6} \mathrm{D}_{6}, \mathrm{RT}\right): \delta=169.9$ $(\mathrm{s}, \mathrm{C}=\mathrm{N}), 165.0(\mathrm{~s}, \mathrm{CO}-\mathrm{Ni}), 150.5,150.1,143.9,143.8\left(\mathrm{~s}, \mathrm{C}^{1}\right), 142.6,141.5$, $140.8\left(\mathrm{~s}, \mathrm{C}^{10}\right), 136.5,134.9,133.0(\mathrm{~s}, \mathrm{CH}), 131.0\left(\mathrm{~s}, \mathrm{C}^{8}\right.$ or $\left.\mathrm{C}^{9}\right), 130.8,127.4$, $126.9\left(\mathrm{~s}, \mathrm{C}^{9}\right.$ or $\left.\mathrm{C}^{8}\right), 126.6(\mathrm{~s}, \mathrm{CH}), 125.8(\mathrm{~s}, \mathrm{CH}), 123.8,123.3,121.2,119.9$ (s, CH), $118.8\left(\mathrm{~s}, \mathrm{C}^{4}\right),-7.3 \mathrm{ppm}(\mathrm{s}, \mathrm{Ni}-\mathrm{Me}) ;{ }^{19} \mathrm{~F} \mathrm{NMR}\left(282.4 \mathrm{MHz}, \mathrm{C}_{6} \mathrm{D}_{6}\right.$, $\mathrm{RT}): \delta=-63.8\left(\mathrm{CF}_{3}\right),-82.0\left(\mathrm{CF}_{2}-\mathrm{CF}_{3}\right),-111.1\left(\mathrm{CF}_{2}\right),-111.5\left(\mathrm{CF}_{2}\right)$, $-122.2\left(\mathrm{CF}_{2}\right),-122.4\left(\mathrm{CF}_{2}\right),-122.9\left(\mathrm{CF}_{2}\right),-123.7\left(\mathrm{CF}_{2}\right),-127.2 \mathrm{ppm}$ $\left(\mathrm{CF}_{2}\right)$; no satisfactory elemental analysis was obtained, as the high fluorine content disturbed the analysis.

Ethylene polymerisation in $\mathbf{s c C O}_{2}$ : The reactions were performed in a stainless steel high-pressure reactor $(10 \mathrm{~mL})$ equipped with glass windows. In a typical experiment, the catalyst $(4 \mu \mathrm{mol})$ was placed in the reactor under inert atmosphere, followed by pressurizing with ethylene to about 40 bar. $\mathrm{CO}_{2}$ was condensed into the reactor from a central highpressure supply at $0^{\circ} \mathrm{C}$. The amount of ethylene and $\mathrm{CO}_{2}$ were determined by weighing the reactor before and after these steps. The reactor was warmed to $50^{\circ} \mathrm{C}$ and stirred $(1000 \mathrm{rpm})$ at this temperature for $1 \mathrm{~h}$. After carefully venting, polyethylene was collected, weighed and subjected directly to further analysis.

\section{Acknowledgements}

A.B. is grateful for a research stipend by the Alexander von Humboldt Foundation. S.M. acknowledges financial support by the BMBF (project 03X5505). We thank Ralf Thomann (Freiburg) for TEM analyses, Georg Mörber (Freiburg) for technical assistance, Lars Bolk for GPC and DSC analyses and Anke Friemel for high-temperature NMR measurements (both Konstanz). Technical support by the staff at the high-pressure labo- 
ratories (Markus Kaever) and the mechanical workshop (Ralf Thelen) at ITMC is also acknowledged. S.M. and W.L. are indebted to the Fonds der Chemischen Industrie for support, and to the Hermann-Schnell Foundation (S.M.). Clariant $\mathrm{GmbH}$ is acknowledged for a gift of perfluorinated surfactants.

[1] a) Chemical Synthesis Using Supercritical Fluids (Eds.: P. G. Jessop, W. Leitner), Wiley-VCH, Weinheim, 1999; b) W. Leitner, Acc. Chem. Res. 2002, 35, 746-756.

[2] Reviews on polymerisation in $\mathrm{scCO}_{2}$ : a) J. L. Kendall, D. A. Canelas, J. L. Young, J. M. DeSimone, Chem. Rev. 1999, 99, 543-563; b) S. L. Wells, J. DeSimone, Angew. Chem. 2001, 113, 534-544; Angew. Chem. Int. Ed. 2001, 40, 518-527; and references therein.

[3] Poly(isobutene) was produced in liquid carbon dioxide: R. H. Biddulph, P. H. Plesch, J. Chem. Soc. 1960, 82, 3913-3920.

[4] J. M. DeSimone, Z. Guan, C. S. Elsbernd, Science 1992, 257, 945947.

[5] a) J. M. DeSimone, E. E. Maury, Y. Z. Menceloglu, J. B. McClain, T. J. Romack, J. R. Combes, Science 1994, 265, 356-359; b) S. Beuermann, M. Buback, C. Schmaltz, F. D. Kuchta, Macromol. Chem. Phys. 1998, 199, 1209-1216.

[6] A. I. Cooper, W. P. Hems, A. B. Holmes, Macromol. Rapid Commun. 1998, 19, 353-357.

[7] Reviews on catalytic synthesis of polymers: a) R. Mülhaupt, Macromol. Chem. Phys. 2003, 204, 289-327; b) Late Transition Metal Polymerisation Catalysis (Eds.: B. Rieger, L. S. Baugh, S. Kacker, S. Striegler), Wiley-VCH, Weinheim, 2003.

[8] G. W. Coates, Chem. Rev. 2000, 100, 1223-1252.

[9] a) L. K. Johnson, S. Mecking, M. Brookhart, J. Am. Chem. Soc. 1996, 118, 267-268; b) S. Mecking, L. K. Johnson, L. Wang, M. Brookhart, J. Am. Chem. Soc. 1998, 120, 888-899.

[10] a) A. Held, F. M. Bauers, S. Mecking, Chem. Commun. 2000, 301302; b) F. M. Bauers, S. Mecking, Macromolecules 2001, 34, 11651171; c) F. M. Bauers, S. Mecking, Angew. Chem. 2001, 113, 31123115; Angew. Chem. Int. Ed. 2001, 40, 3020-3022; d) F. M. Bauers, R. Thomann, S. Mecking, J. Am. Chem. Soc. 2003, 125, 8838-8840; e) L. Kolb, V. Monteil, R. Thomann, S. Mecking, Angew. Chem. 2005, 117, 433-436; Angew. Chem. Int. Ed. 2005, 44, 429-432; f) V. Monteil, P. Wehrmann, S. Mecking, J. Am. Chem. Soc. 2005, 127, 14568-14569; g) I. Göttker-Schnetmann, B. Korthals, S. Mecking, J. Am. Chem. Soc. 2006, 128, in press.

[11] a) A. Tomov, J.-P. Broyer, R. Spitz, Macromol. Symp. 2000, 150, 53 58 ; b) R. Soula, C. Novat, A. Tomov, R. Spitz, J. Claverie, X. Drujon, J. Malinge, T. Saudemont, Macromolecules 2001, 34, $2022-$ 2026; c) R. Soula, B. Saillard, R. Spitz, J. Claverie, M. F. Llaurro, C. Monnet, Macromolecules 2002, 35, 1513-1523.

[12] Reviews: a) S. Mecking, A. Held, F. M. Bauers, Angew. Chem. 2002, 114, 564-582; Angew. Chem. Int. Ed. 2002, 41, 544-561; b) S. Mecking, J. P. Claverie, in Late Transition Metal Polymerisation Catalysis (Eds.: B. Rieger, L. S. Baugh, S. Kacker, S. Striegler), Wiley-VCH: Weinheim, 2003, p. 231-278.

[13] a) A. Fürstner, L. Ackermann, K. Beck, H. Hori, D. Koch, K. Langemann, M. Liebl, C. Six, W. Leitner, J. Am. Chem. Soc. 2001, 123, 9000-9006; b) A. Fürstner, D. Koch, K. Langemann, W. Leitner, C. Six, Angew. Chem. 1997, 109, 2562-2565; Angew. Chem. Int. Ed. Engl. 1997, 36, 2466-2469.

[14] C. D. Mistele, H. H. Thorp, J. M. DeSimone, J. Macromol. Sci. Part A 1996, 33, 953-960.

[15] D. J. Darensbourg, N. W. Stafford, T. Katsurao, J. Mol. Catal. A 1995, 104, L1-L4.

[16] a) C. A. Costello, E. Berluche, S. J. Han, D. A. Sysyn, M. S. Super, E. J. Beckman, Polym. Prepr. 1996, 74, 430; b) M. Duper, E. Berluche, C. Costello, E. Beckman, Macromolecules 1997, 30, 368-372.
[17] H. Hori, C. Six, W. Leitner, Macromolecules 1999, 32, 3178-3182.

[18] L. K. Johnson, C. M. Killian, S. D. Arthur, J. Feldman, E. F. McCord, S. J. McLain, K. A. Kreutzer, M. A. Bennett, E. B. Coughlin, S. D. Ittel, A. Parthasarathy, D. J. Tempel, M. S. Brookhart (DuPont; Univ. North Carolina) WO 96/23010, 1996.

[19] a) T. J. De Vries, R. Duchateau, M. A. G. Vorstman, J. T. F. Keurentjes, Chem. Commun. 2000, 263-264; b) T. J. De Vries, M. F. Kemmere, J. T. F. Keurentjes, Macromolecules 2004, 37, 4241-4246.

[20] a) W. Kläui, J. Bongards, G. J. Reib, Angew. Chem. 2000, 112, 40774079; Angew. Chem. Int. Ed. 2000, 39, 3894-3896; b) "Atomökonomische Synthesen in komprimiertem Kohlendioxid": A. Wegner, Ph.D. Thesis, Universität Jena/MPI für Kohlenforschung, 2000.

[21] a) L. K. Johnson, A. M. A. Bennett, S. D. Ittel, L. Wang, A. Parthasarathy, E. Hauptman, R. D. Simpson, J. Feldman, E. B. Coughlin (DuPont), WO 98/30609, 1998; b) C. Wang, S. Friedrich, T. R. Younkin, R. T. Li, R. H. Grubbs, D. A. Bansleben, M. W. Day, Organometallics 1998, 17, 3149-3151; c) D. A. Bansleben, S. Friedrich, T. R. Younkin, R. H. Grubbs, C. Wang, R. T. Li (W. R. Grace), WO 98/ 42664, 1998; d) T. R. Younkin, E. F. Connor, J. I. Henderson, S. K. Friedrich, R. H. Grubbs, D. A. Bansleben, Science 2000, 287, 460462.

[22] M. A. Zuideveld, P. Wehrmann, C. Röhr, S. Mecking, Angew. Chem. 2004, 116, 887-891; Angew. Chem. Int. Ed. 2004, 43, 869-873.

[23] a) S. Kainz, D. Koch, W. Baumann, W. Leitner, Angew. Chem. 1997, 109, 1699-1701; Angew. Chem. Int. Ed. Engl. 1997, 36, 1628-1630; b) W. Leitner, Nature 2000, 405, 129-130.

[24] P. Bhattacharyya, D. Gudmunsen, E. G. Hope, R. D. W. Kemmitt, D. R. Paige, A. M. Stuart, J. Chem. Soc. Perkin Trans. 1 1997, 36093612.

[25] M. Schmid, R. Eberhardt, M. Klinga, M. Leskelä, B. Rieger, Organometallics 2001, 20, 2321-2330.

[26] P. Wehrmann, M. A. Zuideveld, R. Thomann, S. Mecking, Macromolecules 2006, 39 , in press.

[27] The number of perfluorinated ponytails, rather than the actual fluorine content, seems to be the decisive factor in determining the solubility of perfluorinated compounds. R. Annunziata, M. Benaglia, M. Cinquini, F. Cozzi, G. Pozzi, Eur. J. Org. Chem. 2003, 1191-1197.

[28] Perfluoroalkyl-substituted salicylaldehyde has been previously prepared by a five-step synthesis: G. Pozzi, F. Cinato, F. Montanari, S. Quici, Chem. Commun. 1998, 877-878.

[29] G. Franciò, K. Wittmann, W. Leitner, J. Organomet. Chem. 2001 $621,130-142$.

[30] 5a: $30 \mu \mathrm{mol}$ dissolve completely at $40^{\circ} \mathrm{C}$ and $\rho\left(\mathrm{CO}_{2}\right)=1.14 \mathrm{~g} \mathrm{~mL}^{-1}$ in $13 \mathrm{~mL}$; $5 \mathbf{c}: 33 \mu \mathrm{mol}$ at $20^{\circ} \mathrm{C} \rho\left(\mathrm{CO}_{2}\right)=0.49 \mathrm{~g} \mathrm{~mL}^{-1}$ in $13 \mathrm{~mL}$.

[31] W. Kaschube, K. R. Poerschke, G. Wilke, J. Organomet. Chem. 1988, $355,525-532$

[32] E. F. Connor, T. R. Younkin, J. I. Henderson, A. W. Waltman, R. H. Grubbs, Chem. Commun. 2003, 18, 2272-2273.

[33] U. Kreher, S. Schebesta, D. Walther, Z. anorg. allg. Chem. 1998, 624, 602-612.

[34] T. Yamamoto, A. Yamamoto, Chem. Letters, 1978, 6, 615-616.

[35] F. M. Mirabella, A. Bafna, J. Polym. Sci. Part B 2002, 40, 1637.

[36] a) P. Wehrmann, Diploma Thesis, Universität Freiburg, 2003; b) A. Bastero, L. Kolb, P. Wehrmann, F. Bauers, I. Goettker-Schnetmann, V. Monteil, R. Thomann, M. Chowdhry, S. Mecking, PMSE Prepr. 2004, 90,740 .

[37] E. W. Lemmon, M. O. McLinden, D. G. Friend, Thermophysical Properties of Fluid Systems, http://webbook.nist.gov, 2005.

[38] U. Plöcker, H. Knapp, J. Prausnitz, Ind. Eng. Chem. Process Des. Dev. 1978, 17, 324-332.

[39] J. Morgan, J. T. Pinhey, J. Chem. Soc. Perkin Trans. 1 1990, 715-720. 